\title{
Article \\ Photoelectrochemical Oxidation in Ambient Conditions Using Earth-Abundant Hematite Anode: A Green Route for the Synthesis of Biobased Polymer Building Blocks
}

\author{
Anurag Kawde ${ }^{1,2, *,+}$, Mahmoud Sayed ${ }^{3,4,+}{ }^{-}$, Qi Shi ${ }^{2}$, Jens Uhlig ${ }^{1,2}$, , Tönu Pullerits ${ }^{2, *}$ \\ and Rajni Hatti-Kaul ${ }^{3, *} \neq$ (iD) \\ 1 Lund Institute of Advanced Neutron and X-ray Science, Lund University, \\ P.O. Box 124, SE-22100 Lund, Sweden; Jens.uhlig@chemphys.lu.se \\ 2 Chemical Physics and NanoLund, Department of Chemistry, Lund University, \\ P.O. Box 124, SE-22100 Lund, Sweden; qi.shi@chemphys.lu.se \\ 3 Division of Biotechnology, Department of Chemistry, Lund University, P.O. Box 124, SE-22100 Lund, Sweden; \\ mahmoud.sayed_ali_sayed@biotek.lu.se \\ 4 Department of Botany and Microbiology, Faculty of Science, South Valley University, Qena 83523, Egypt \\ * Correspondence: anurag.kawde@linxs.lu.se (A.K.); tonu.pullerits@chemphys.lu.se (T.P.); \\ rajni.hatti-kaul@biotek.lu.se (R.H.-K.) \\ + Authors contributed equally. \\ $\ddagger$ Lead Contact.
}

check for updates

Citation: Kawde, A.; Sayed, M.; Shi, Q.; Uhlig, J.; Pullerits, T.; Hatti-Kaul, R. Photoelectrochemical Oxidation in Ambient Conditions Using Earth-Abundant Hematite Anode: A Green Route for the Synthesis of Biobased Polymer Building Blocks. Catalysts 2021, 11, 969. https:// doi.org/10.3390/catal11080969

Academic Editor: Carlo Santoro

Received: 26 June 2021

Accepted: 12 August 2021

Published: 13 August 2021

Publisher's Note: MDPI stays neutral with regard to jurisdictional claims in published maps and institutional affiliations.

Copyright: (c) 2021 by the authors. Licensee MDPI, Basel, Switzerland. This article is an open access article distributed under the terms and conditions of the Creative Commons Attribution (CC BY) license (https:/ / creativecommons.org/licenses/by/ $4.0 /)$.

\begin{abstract}
This study demonstrates the use of a photoelectrochemical device comprising earthabundant hematite photoanode for the oxidation of 5-hydroxymethylfurfural (5-HMF), a versatile bio-based platform chemical, under ambient conditions in the presence of an electron mediator. The results obtained in this study showed that the hematite photoanode, upon doping with fluorine, can oxidize water even at lower $\mathrm{pH}$ (4.5 and 9.0). For 5-HMF oxidation, three different $\mathrm{pH}$ conditions were investigated, and complete oxidation to 2,5-furandicarboxylic acid (FDCA) via 5-hydroxymethyl-2furancarboxylic acid (HMFCA) was achieved at $\mathrm{pH}$ above 12. At lower $\mathrm{pH}$, the oxidation followed another route via 2,5-diformylfuran (DFF), yielding 5-formyl-2-furancarboxylic acid (FFCA) as the main product. Using the oxidized intermediates as substrates showed DFF to be most efficiently oxidized to FDCA. We also show that, at $\mathrm{pH} 4.5$, the addition of the laccase enzyme promoted the oxidation of 5-HMF to FFCA.
\end{abstract}

Keywords: photoelectrochemical cell; earth-abundant hematite photoanode; bio-based chemicals; 5-HMF oxidation; 2,5-furandicarboxylic acid

\section{Introduction}

The tremendous growth in the chemical manufacturing industry during the past century has relied heavily on exploiting fossil resources to provide both carbon for the chemicals and materials as well as energy for the processes. The chemical manufacturing contributes nearly $20 \%$ of the global greenhouse gas emissions (amounting to $880 \mathrm{Mt} \mathrm{CO}_{2}$ equivalent in 2018) [1,2]. Replacing fossil energy with a renewable alternative such as solar energy and using biomass for providing renewable carbon provides a sustainable route for a fossil-free chemical industry of the future [3-5]. In general, high energetic compounds are an excellent way to store harvested solar energy without the drawback of battery technology and are the basic idea behind photoelectrochemical cells (PECs) [3]. In a typical PEC operation, water is oxidized $\left(2 \mathrm{H}_{2} \mathrm{O} \rightarrow \mathrm{O}_{2}+4 \mathrm{H}^{+}\right)$at the semiconductor photoanode, while the protons liberated in this reaction migrate to the cathode to conduct a reduction reaction $\left(4 \mathrm{H}^{+}+4 \mathrm{e}^{-} \rightarrow 2 \mathrm{H}_{2}\right)$ [6,7]. The produced $\mathrm{H}_{2}$ is the significant energetic product stored for further use, and the second product, $\mathrm{O}_{2}$, is of low industrial value [3,5]. An alternative oxidation reaction that produces instead high-value chemicals at the photoanode [8] could 
significantly increase the fraction of stored energy as well as the efficiency of the system. The design criteria of such photoelectrodes are earth-abundant materials such as $\mathrm{Si}[9,10]$, $\mathrm{Fe}_{2} \mathrm{O}_{3}$ [11], $\mathrm{CuO}_{2}$ [12], or $\mathrm{BiVO}_{4}$ [13] that further reduce the cost and increase the scalability of the system, hence improving the cost-benefit ratio.

The reaction that has attracted considerable interest to replace water oxidation $\left(\mathrm{O}_{2}\right.$ production) in recent years is the oxidation of 5-hydroxymethylfurfural (5-HMF) to 2,5furandicarboxylic acid (FDCA). The U.S. Department of Energy (DOE) has ranked 5-HMF and FDCA among the top value-added biomass-based chemicals [14]. While 5-HMF constitutes an essential platform for a large number of chemicals, including fuels, solvents, and polymer building blocks [15], FDCA is regarded as a sustainable alternative to terephthalic acid in the production of polyester polyethylene 2,5-furandicarboxylate (PEF) with better thermomechanical and barrier properties than polyethylene terephthalate (PET) [16] FDCA is produced from 5-HMF through three oxidation steps, which can take two different routes, as shown in Scheme 1. Oxidation of 5-HMF has been reported using chemical [17,18], biocatalytic [19], electrochemical [20], or photoelectrochemical catalysis [5].

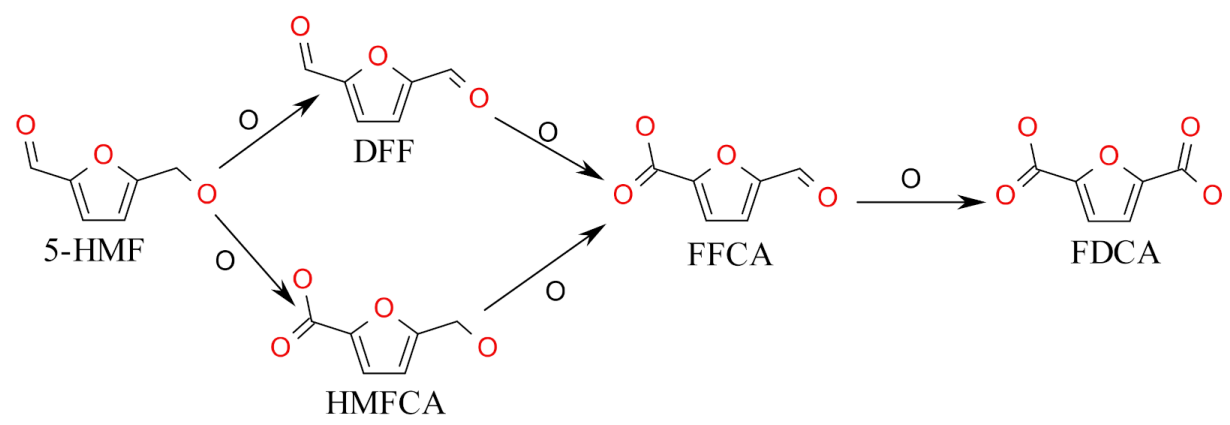

Scheme 1. Two possible pathways for oxidation of 5-HMF. The intermediates produced during the oxidation are as follows: 2,5-diformylfuran (DFF), 5-hydroxymethyl-2-furan-carboxylic acid (HMFCA), and 5-formyl-2-furoic acid (FFCA).

Earlier reports on the electrochemical oxidation of 5-HMF have indicated the need for large electroactive surfaces and high catalyst loadings to obtain high reaction rates and selective formation of FDCA [20]. A photoelectrochemical (PEC) system that utilizes solar energy for oxidation can be one of the most lucrative and clean options [21,22] Photoinduced electron-hole pairs are generated at the valence band of the photoanode, and while the electrons are transferred to the cathode, the holes can be utilized at the anode for the oxidation reaction [3]. In the past few years, various studies using earth-abundant photoelectrodes/catalysts for the oxidation of 5-HMF have been reported using varying illumination intensities and varying 5-HMF concentrations [5,19,23]. Moreover, most of these systems have been operated at elevated temperatures. For the practical application of a system driven by solar light, it needs to work at a maximum of $100 \mathrm{~mW} / \mathrm{cm}^{2}$, which is the power density of a typical solar illumination at airmass filter of $1.5 \mathrm{G}$ observed on the Earth [24]. Moreover, using as high a 5-HMF concentration as possible decreases the cost of product recovery from the reaction. Herein, we report the use of earth-abundant hematite photoanode for the PEC conversion of 5-HMF under ambient conditions of temperature $\left(21^{\circ} \mathrm{C}\right)$ and pressure, as well as different $\mathrm{pH}$ values.

\section{Results and Discussion}

\subsection{Photolectrochemical Water Oxidation Using Hematite Nanorods}

The (photo-)electrochemical oxidation is typically performed under alkaline conditions at which 5-HMF is prone to degradation into humin products [25]. On the other hand, the hematite surface is spontaneously corroded by the protons in the electrolyte in acidic or neutral conditions [26]. Thus, we tested the hematite photoanode performance at three different $\mathrm{pH}$ conditions (4.5, 9.0, and 12.5) first for water oxidation followed by 
5-HMF oxidation. The hematite photoanode was synthesized on the conductive fluorine tin oxide (FTO) substrate to yield $\mathrm{FTO} / \alpha-\mathrm{Fe}_{2} \mathrm{O}_{3}$ following the method reported by Vayssieres et al. [27]. The FTO $/ \alpha-\mathrm{Fe}_{2} \mathrm{O}_{3}$ (bare hematite) was further modified by soaking in the fluoride-rich iron-oxide electrolyte $\left(1 \mathrm{mM} \mathrm{NH}_{4} \mathrm{~F}\right.$ in $\left.0.15 \mathrm{M} \mathrm{FeCl}_{3}\right)$ to yield fluorinedoped $\mathrm{FTO} / \alpha-\mathrm{Fe}_{2} \mathrm{O}_{3} / \mathrm{FeOOH}$ (modified hematite) photoelectrode (see the Experimental section for detailed synthesis method). The morphological characterization (X-ray diffraction and scanning electron micrograph) of the photoelectrode is presented in Figure S1. The XRD (Figure S1a) for the bare and modified hematite overlaps for most phases except for the presence of a small distinctive peak at $23.8 \mathrm{deg}$, indicating the (110) phase of FeOOH. Figure S1b,c show the planar top view of the bare and modified hematite photoanode wherein the modified hematite shows a thin film formed on top of bare hematite.

The photoelectrode was placed in a photoelectrochemical cell. The net photocurrent density (photocurrent-dark current) $\mathrm{J}_{\mathrm{ph}}$ was recorded at $1.23 \mathrm{~V}_{\mathrm{RHE}}$ (voltage vs. reversible hydrogen electrode) for the bare hematite photoelectrode at $\mathrm{pH} 4.5,9.0$, and 12.5, giving $0.05,0.1$, and $0.48 \mathrm{~mA} / \mathrm{cm}^{2}$, respectively (Figure 1 dark gray color bar). The respective current-potential curves are shown in Figure S2a,b. Upon doping with fluorine, the $\mathrm{J}_{\mathrm{ph}}$ at $1.23 \mathrm{~V}_{\mathrm{RHE}}$ for the modified hematite photoelectrode increased significantly to $0.1,0.16$, and $1.18 \mathrm{~mA} / \mathrm{cm}^{2}$ at $\mathrm{pH} 4.5,9.0$, and 12.5 , respectively (Figure 1 wine color bar), indicating the PEC performance of the $\alpha-\mathrm{Fe}_{2} \mathrm{O}_{3}$ photoanode to be enhanced when functionalized with $\mathrm{F}$-doped $\mathrm{FeOOH}$. The effect is attributed to the reduced recombination losses at the surface of the $\alpha-\mathrm{Fe}_{2} \mathrm{O}_{3}$ nanorods and enhanced charge transfer through the $\mathrm{FeOOH}$, consistent with recent reports on F-doped hematite for water oxidation [28,29]. Thus, the F-doped $\mathrm{FeOOH}$ avoids the corrosion of the hematite electrode surface and enhances charge transfer even in mildly acidic electrolytes.

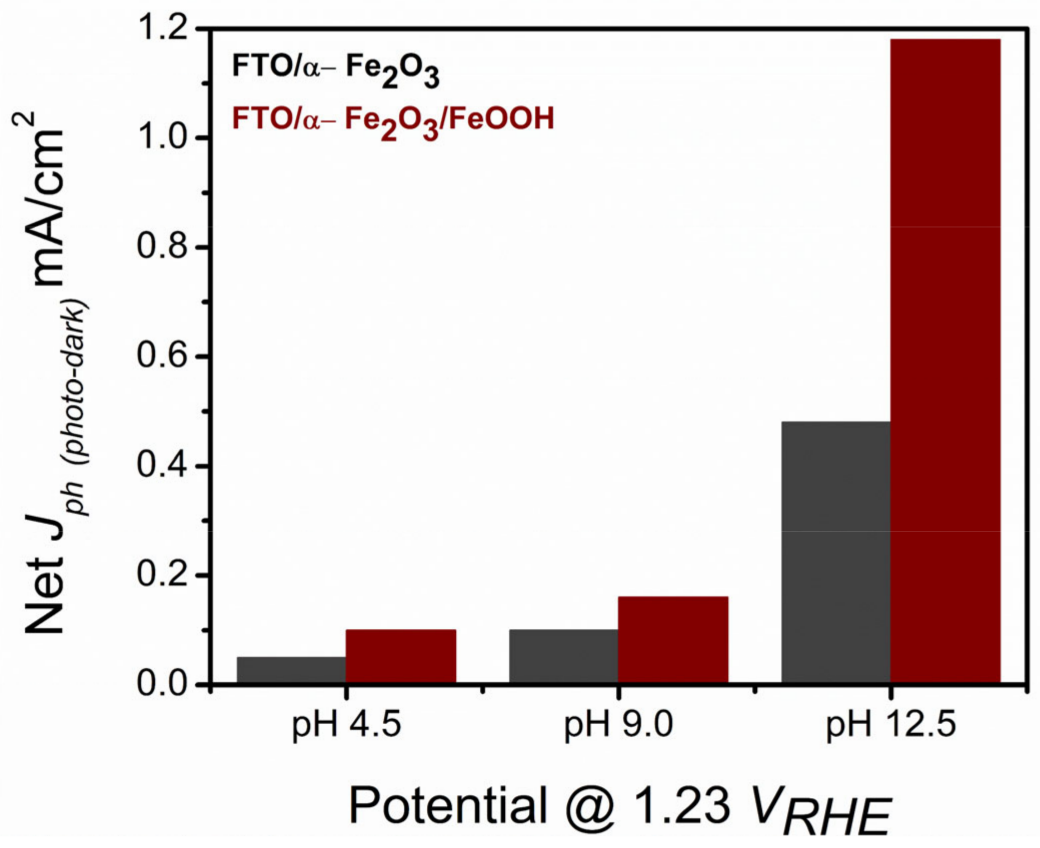

Figure 1. Net photocurrent responses for bare and modified hematite photoanodes for water oxidation at $1.23 V_{\text {RHE. }}$

\subsection{Photolectrochemical 5-HMF Oxidation}

Subsequently, we evaluated the PEC performance of the modified hematite photoelectrode for the oxidation of 5-HMF, which was produced from fructose, using the method adopted from our previous study [30]. Figure 2a shows the current potential curves recorded for 5-HMF oxidation at $\mathrm{pH} 12.5$ in $1 \mathrm{M} \mathrm{Na}_{2} \mathrm{SO}_{4}$, and the corresponding chronoamperometry (CA) response (Figure $2 \mathrm{~b}$ ) recorded at 1.1 VRHE. Interestingly, we found that the onset potential $\left(\mathrm{V}_{\text {onset }}\right)[10]$, defined here as the potential at which net 
photocurrent density $\left(\mathrm{J}_{\mathrm{ph}}\right)$ reaches $0.1 \mathrm{~mA} / \mathrm{cm}^{2}$, decreases by $30 \mathrm{mV}$ from 0.81 to $0.78 \mathrm{~V}_{\mathrm{RHE}}$ in the presence of $10 \mathrm{mM} 5$-HMF. This indicates that the oxidation of 5-HMF is favored over water oxidation. Additionally, $\mathrm{J}_{\mathrm{ph}}$ of $1.8 \mathrm{~mA} / \mathrm{cm}^{2}$ was recorded for modified hematite at $1.4 \mathrm{~V}_{\mathrm{RHE}}$, which is $64 \%$ higher than that without 5-HMF. Similarly, the onset potential further decreases with the addition of 2,2,6,6-tetramethyl piperidine-1-yl)oxidanyl (TEMPO), a well-known artificial electron mediator [31]. Addition of $1 \mathrm{mg} / \mathrm{mL}$ and $2 \mathrm{mg} / \mathrm{mL}$ of TEMPO (6.4 mM and $12.8 \mathrm{mM})$ in the $10 \mathrm{mM}$ 5-HMF solution decreases the $\mathrm{V}_{\text {onset }}$ by $90 \mathrm{mV}$ to $0.72 \mathrm{~V}_{\mathrm{RHE}}$ and by $220 \mathrm{mV}$ to $0.59 \mathrm{~V}_{\mathrm{RHE}}$, respectively, indicating that the oxidation of TEMPO is significantly favorable over that of 5-HMF (see Table S1 for a summary). The addition of TEMPO decreased the $\mathrm{V}_{\text {onset }}$ and led to a phenomenal increase in the PEC performance of the 5-HMF oxidation system. We recorded the $\mathrm{J}_{\mathrm{ph}}$ of $3.2 \mathrm{~mA} / \mathrm{cm}^{2}$ at $1.4 \mathrm{~V}_{\mathrm{RHE}}$ for $1 \mathrm{mg} / \mathrm{mL}$ TEMPO that increased by more than a factor 2 to $7.8 \mathrm{~mA} / \mathrm{cm}^{2}$ on doubling the mediator concentration. TEMPO takes the photogenerated holes from $\alpha-\mathrm{Fe}_{2} \mathrm{O}_{3}-\mathrm{FeOOH}$ and is oxidized to TEMPO ${ }^{+}$(oxo cation), which in turn oxidizes 5-HMF while simultaneously regenerating the TEMPO. Our observations agree with Cha and Choi [5] in that the shift (decrease) in the anodic onset potential by the addition of TEMPO significantly reduces the overpotential for 5-HMF oxidation without competing with water oxidation. As evident from Figure $2 \mathrm{~b}$, the photocurrent reaches a plateau after $3 \mathrm{~h}$ of $\mathrm{CA}$, indicating that most of the 5-HMF is oxidized. The details of 5-HMF conversion under different conditions are given in Table 1.

Table 1. Photoelectrochemical oxidation of 5-HMF and derivatives using hematite photoanode at $20^{\circ} \mathrm{C}$ and different $\mathrm{pH}$ values.

\begin{tabular}{|c|c|c|c|c|c|c|c|c|}
\hline \multicolumn{9}{|c|}{ Experiment pH 12.5} \\
\hline \multirow{2}{*}{ Experiment at $1.1 \mathrm{~V}_{\mathrm{RHE}}$} & \multirow{2}{*}{$\begin{array}{c}\text { 5-HMF } \\
\text { Conversion }(\%)\end{array}$} & \multirow{2}{*}{ Time (h) } & \multicolumn{4}{|c|}{ Product Profile (Selectivity \%) } & \multicolumn{2}{|c|}{$\mathrm{pH}$} \\
\hline & & & 5-HMFCA & DFF & FFCA & FDCA & Start & End \\
\hline $10 \mathrm{mM}$ 5-HMF & 11.7 & 20 & 83.9 & 7.8 & 6.4 & 1.8 & 12.5 & 10 \\
\hline $10 \mathrm{mM}$ 5-HMF + $1 \mathrm{mg} / \mathrm{mL}$ TEMPO & 42 & 20 & 71.1 & 1.4 & 4.1 & 23.4 & 12.5 & 11 \\
\hline $10 \mathrm{mM}$ 5-HMF + $2 \mathrm{mg} / \mathrm{mL}$ TEMPO & 96.6 & 2.5 & 0.4 & 0.3 & 18.4 & 80.9 & 12.5 & 11 \\
\hline $10 \mathrm{mM}$ 5-HMF + $2 \mathrm{mg} / \mathrm{mL}$ TEMPO & 99.2 & 5.5 & 0.5 & 2.2 & 6.4 & 90.7 & 12.5 & 11 \\
\hline \multicolumn{9}{|c|}{ Experiment pH 9.0} \\
\hline \multirow{2}{*}{ Experiment at $1.1 \mathrm{~V}_{\mathrm{RHE}}$} & \multirow{2}{*}{ Conversion $(\%)$} & \multirow{2}{*}{ Time (h) } & \multicolumn{4}{|c|}{ Product profile (Selectivity \%) } & \multicolumn{2}{|c|}{$\mathrm{pH}$} \\
\hline & & & 5-HMFCA & DFF & FFCA & FDCA & Start & End \\
\hline 10 mM 5-HMF + 2 mg/mL TEMPO & 47.3 & 20 & 1.5 & 31.7 & 66.2 & 1.6 & 9.0 & 5 \\
\hline $\begin{array}{c}10 \mathrm{mM} \text { 5-HMFCA + } \\
2 \mathrm{mg} / \mathrm{mL} \text { TEMPO }\end{array}$ & 50.9 & 20 & - & - & 5.7 & 94.2 & 9.0 & 6 \\
\hline $10 \mathrm{mM}$ DFF + $2 \mathrm{mg} / \mathrm{mL}$ TEMPO & 90.1 & 20 & - & - & 96.1 & 2.6 & 9.0 & 5 \\
\hline $10 \mathrm{mM}$ FFCA + $2 \mathrm{mg} / \mathrm{mL}$ TEMPO & 40.6 & 20 & - & - & - & 97.4 & 9.0 & 5 \\
\hline \multicolumn{9}{|c|}{ Experiment pH 4.5} \\
\hline \multirow{2}{*}{ Experiment at $1.1 \mathrm{~V}_{\mathrm{RHE}}$} & \multirow{2}{*}{ Conversion $(\%)$} & \multirow{2}{*}{ Time (h) } & \multicolumn{4}{|c|}{ Product profile (Selectivity \%) } & \multicolumn{2}{|c|}{$\mathrm{pH}$} \\
\hline & & & 5-HMFCA & DFF & FFCA & FDCA & Start & End \\
\hline $10 \mathrm{mM}$ 5-HMF + $2 \mathrm{mg} / \mathrm{mL}$ TEMPO & 51.7 & 20 & 1.6 & 29.6 & 67.3 & 1.5 & 4.5 & 4 \\
\hline $10 \mathrm{mM}$ 5-HMF + $0.5 \mathrm{mg} / \mathrm{mL}$ Laccase & 14.9 & 20 & 21.4 & 53.5 & 24.1 & 1.0 & 4.5 & 4 \\
\hline $\begin{array}{c}10 \mathrm{mM} \text { 5-HMF + } 2 \mathrm{mg} / \mathrm{mL} \text { TEMPO + } \\
0.5 \mathrm{mg} / \mathrm{mL} \text { Laccase }\end{array}$ & 78.3 & 20 & 0.7 & 7.7 & 85.9 & 5.7 & 4.5 & 4 \\
\hline
\end{tabular}


a

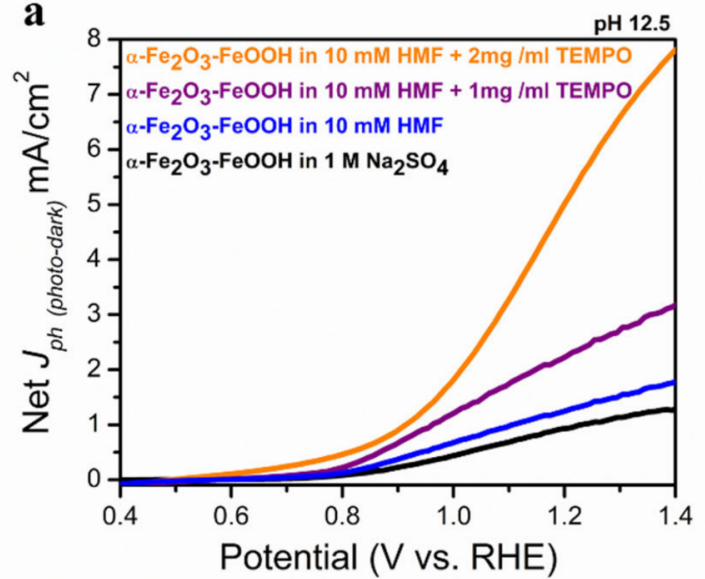

b

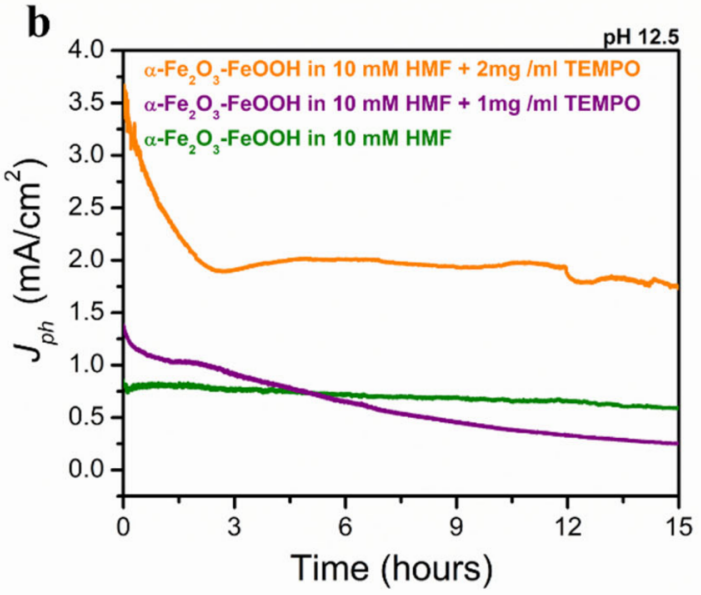

Figure 2. (a) Net photocurrent responses for 5-HMF photooxidation at $\mathrm{pH} 12.5$ and (b) corresponding chronoamperometry (CA) response at $1.1 V_{\mathrm{RHE}}$.

Based on the decreased $\mathrm{V}_{\text {onset }}$ and higher $\mathrm{J}_{\mathrm{ph}}$ obtained at $2 \mathrm{mg} / \mathrm{mL}$ of TEMPO, we performed PEC oxidation of 5-HMF at $\mathrm{pH} 9.0$ and 4.5. Figure $3 \mathrm{a}, \mathrm{b}$ show the current potential curves recorded at the two $\mathrm{pH}$ values; the $\mathrm{V}_{\text {onset }}$ followed a similar trend at $\mathrm{pH}$ 9.0 and 4.5 as at $\mathrm{pH} 12.5$. The $\mathrm{V}_{\text {onset }}$ decreased by $410 \mathrm{mV}$ in the presence of 5-HMF and was further reduced by $230 \mathrm{mV}$ upon the addition of TEMPO. Likewise, the $J_{p h}$ at $1.4 V_{\mathrm{RHE}}$ was increased by more than a factor of 2 in the presence of 5-HMF and by almost a factor of 7 upon the addition of TEMPO. At $\mathrm{pH} 4.5$, the $\mathrm{V}_{\text {onset }}$ reduced significantly by $390 \mathrm{mV}$ in the presence of 5-HMF and by $720 \mathrm{mV}$ by further addition of TEMPO. Similarly, almost a factor of 2 and 11 increase in $\mathrm{J}_{\mathrm{ph}}$ was recorded at $1.4 \mathrm{~V}_{\mathrm{RHE}}$ in the presence of 5-HMF and upon further addition of TEMPO, respectively. As the hematite bandgap is $2.1 \mathrm{eV}$ (valence-band edge at $\sim 2.3 \mathrm{~V}$ vs. RHE) [8,32], the photogenerated holes in the hematite have sufficient potential to oxidize TEMPO. Thus, the additional bias potential enhances electron-hole separation, increasing the oxidation at the photoanode surface [33]. According to cyclic voltammetry of TEMPO performed in an earlier report [34], the reversible electrochemical oxidation of TEMPO is insensitive to $\mathrm{pH}$ and the nature of the buffer used. The cyclic voltammograms for the oxidation of 5-HMF in dark and under illumination performed in this study are presented in Figure S3, indicating a typical redox behavior of TEMPO under different $\mathrm{pH}$ conditions.

These observations confirmed that the modified hematite photoanode can work efficiently for 5-HMF oxidation at different $\mathrm{pH}$ values in the presence of a mediator without interfering with the water oxidation reaction. The products formed during photoelectrochemical oxidation of 5-HMF under different conditions at $\mathrm{pH} 4.5,9.0$, and 12.5, respectively, are presented in Table 1 . The corresponding chronoamperometry (CA) response recorded at $1.1 \mathrm{~V}_{\mathrm{RHE}}$ is shown in Figure $2 \mathrm{~b}$ and the Supplementary Materials (Figures S4 and S5a). We observed the 5-HMF photooxidation to be highly $\mathrm{pH}$-dependent, in agreement with the earlier study [19]. Control measurements performed in the dark at different $\mathrm{pH}$ values did not show any detectable oxidation of 5-HMF (data not shown). As shown in Table 1, we achieved only $11.7 \%$ photoconversion of $5-\mathrm{HMF}$ at $\mathrm{pH} 12.5$ without a mediator; the significant fraction (83.9\%) was converted to 5-hydroxymethyl-2-furancarboxylic acid (HMFCA), and the $\mathrm{pH}$ of the solution decreased to 10 at the end of the $20 \mathrm{~h} \mathrm{CA}$ run. Supplementation of $1 \mathrm{mg} / \mathrm{mL}$ TEMPO resulted in $42 \%$ of $5-\mathrm{HMF}$ being oxidized, of which $23.4 \%$ was FDCA and the remaining HMFCA, suggesting that oxidation occurs via route 2 shown in Figure 4. On increasing the TEMPO concentration to $2 \mathrm{mg} / \mathrm{mL}$, nearly 97\% 5-HMF was converted in $2.5 \mathrm{~h}$ to yield over $80 \%$ FDCA, and continuing the reaction resulted in almost $100 \%$ of the 5-HMF being oxidized to give FDCA at $>90 \%$ yield in $5.5 \mathrm{~h}$. This corresponds to the incident photon-to-current efficiency of $9.29 \%$ and the Faradic efficiency of $92.6 \%$. The earlier report using $\mathrm{BiVO}_{4}$ photoelectrode revealed no oxidation of 5-HMF in the absence of TEMPO [5]. On the other hand, the high surface area nickel boride electrode providing 
high current density of around $50 \mathrm{~mA} / \mathrm{cm}^{2}$ at a constant potential of $1.45 \mathrm{~V}_{\mathrm{RHE}}$ (which is about six times higher than that in the present study) used for electrochemical oxidation showed 100\% 5-HMF conversion to FDCA in just half an hour [20].
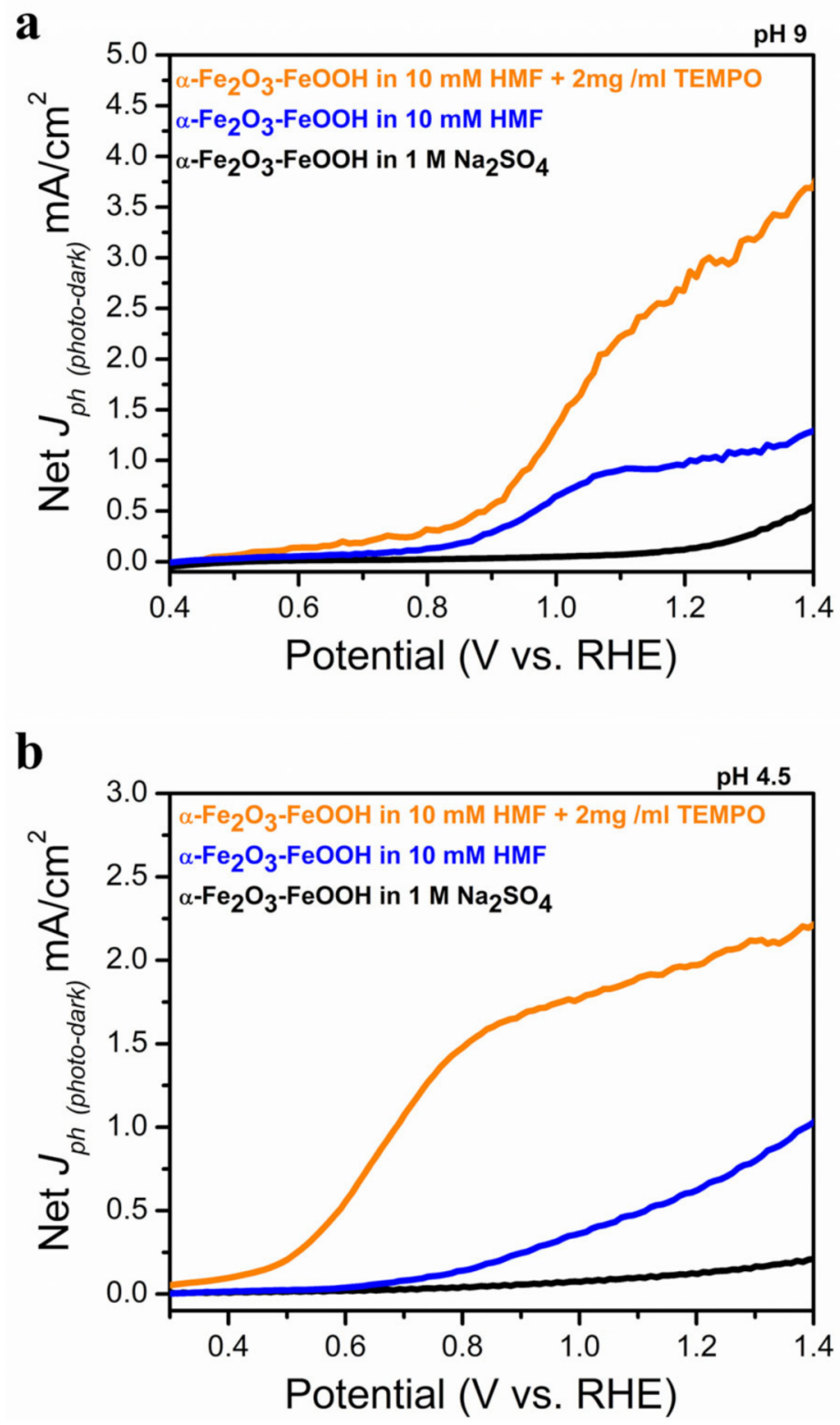

Figure 3. Net photocurrent responses for 5-HMF photooxidation at $\mathrm{pH}$ (a) 9.0 and (b) 4.5 .

As seen in Table 1, the efficiency of oxidation decreases at lower $\mathrm{pH}$ values. At $\mathrm{pH} 9$, 5-HMF was partially converted to a mixture of the route 1 intermediates 2,5-diformylfuran (DFF) and 5-formyl-2-furoic acid (FFCA) (Figure 4), the latter being present in a higher proportion. Reactions performed using FFCA, DFF, and HMFCA, respectively, as substrates under the same conditions showed DFF to be most efficiently converted with high selectivity to FFCA. On the other hand, HMFCA and FFCA were partly converted, but with high selectivity to FDCA. In all the experiments starting at $\mathrm{pH} 9.0$, the $\mathrm{pH}$ was decreased to 5.0 ( $\mathrm{pH} 6$ in case of 5-HMFCA). The corresponding CA and current potential curves shown in Figures S5b-d and S6, respectively, indicate that the FFCA oxidation step is the slowest, in accordance with the previous report [5]. This corresponds to the incident photon-to-current efficiency of $6.07 \%$ and the Faradic efficiency of $12.6 \%$. 


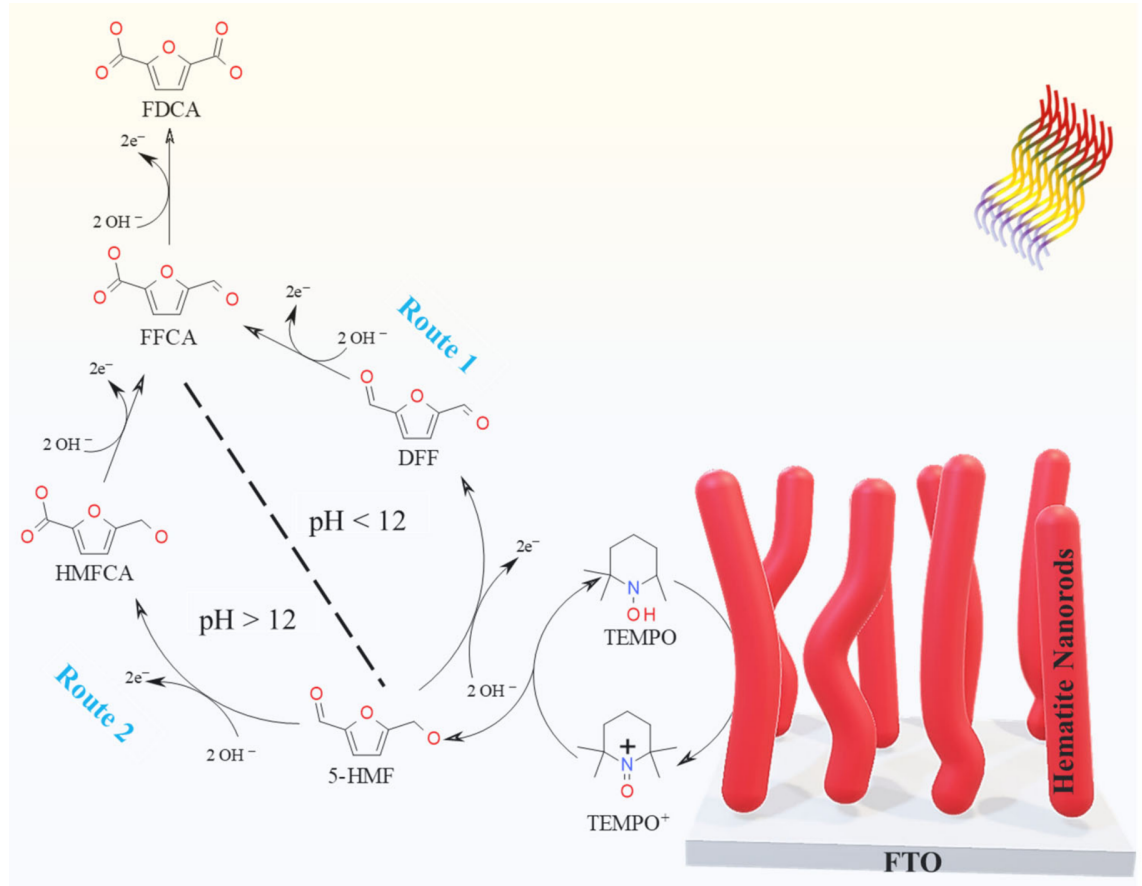

Figure 4. Schematic representation of the possible pathways of 5-HMF oxidation to FDCA at $\mathrm{pH}$ higher than 12.0 and $\mathrm{pH}$ less than 12.0 .

5-HMF oxidation at $\mathrm{pH} 4.5 \mathrm{in}$ the presence of $2 \mathrm{mg} / \mathrm{mL}$ TEMPO showed a similar pattern as at $\mathrm{pH} 9$ (Figure 4), corresponding to the incident photon-to-current efficiency of $5.14 \%$ and the Faradic efficiency of $17.7 \%$. The addition of the enzyme laccase (from Trametes versicolor) to the system significantly increased (78\%) the degree of 5-HMF conversion, yielding FFCA as the main product. Laccases are multicopper oxidases found in plants, fungi, and bacteria, which catalyze the oxidation of phenolic and non-phenolic compounds while reducing oxygen to water [35]. The enzyme was not effective in the absence of TEMPO (Table 1).

The results obtained in this study are thus comparable to those in the earlier reports on photoelectrochemical oxidation of 5-HMF (Table S2). In the literature, three other PEC devices come closest to the efficiency we achieved in this study with a very inexpensive system. One device is a $\mathrm{Ni} / \mathrm{CdS}$ nanosheet photoelectrode, which showed highly efficient oxidation of 5-HMF at the incredible power of $8 \mathrm{~W} / \mathrm{cm}^{2}$ and operated at a significantly raised temperature (cost and necessary temperature control) [23]. This light intensity is an 80 -fold increase to the typical solar irradiation of $100 \mathrm{~mW} / \mathrm{cm}^{2}$ used in this study. The second study uses $\mathrm{CoPz} / \mathrm{g}-\mathrm{C}_{3} \mathrm{~N}_{4}$ under five times stronger illumination $\left(500 \mathrm{~mW} / \mathrm{cm}^{2}\right)$ and achieved 99.1\% 5-HMF conversion at $\mathrm{pH}$ 9.18. This device operates at nearly 10 times lower 5-HMF concentration, significantly limiting the achievable conversion yields [19]. Closest to our system comes one reported device based upon a $\mathrm{BiVO}_{4}$ electrode operated at elevated temperatures and functioning only in the presence of TEMPO [5]. In most studies, a higher operating temperature was suggested to play a critical role in the selective conversion of 5-HMF to FDCA. We highlight that our study is performed under ambient conditions, with a relatively higher concentration of 5-HMF $(10 \mathrm{mM})$ and at the illumination power density of $100 \mathrm{~mW} / \mathrm{cm}^{2}$, representing the typical solar irradiation conditions.

In accordance with the report by Shuai et al. [19], it is evident that 5-HMF photooxidation using the modified hematite photoanode in the present study follows different routes depending on the $\mathrm{pH}$ of the electrolyte solution (Figure 4). It was indicated that a higher $\mathrm{pH}$ promotes the formation of alcohols and acids following the Cannizzaro mechanism, resulting in the two different $\mathrm{pH}$-dependent mechanisms for 5-HMF oxidation. We also found that DFF and FFCA are unstable at higher $\mathrm{pH}$, which is evident from the initial HPLC chromatograms shown in Figure S7. 
As shown in Figure 4, with every oxidation step, two electrons are released in the solution (in total, six electrons) that are used in TEMPO regeneration. Considering that the reduction reaction at the counter electrode also plays a significant role in the photooxidation of 5-HMF, we believe that, at a low $\mathrm{pH}$ where the concentration of protons is comparatively higher, the FDCA yield is compensated by the reduction reaction at the cathode ( $\mathrm{H}_{2}$ generation). It would thus be important to study the 5-HMF oxidation in a dual-compartment cell separated by a Nafion membrane where both the oxidation and reduction reactions are separated to investigate the mass transfer limitations during 5-HMF photooxidation. It would also be interesting to study the reaction kinetics using recently developed in situ femtosecond transient absorption spectroscopy combined with spectroelectrochemistry techniques [36].

\section{Experimental}

\subsection{Materials}

Analytical-grade furan compounds FDCA, FFCA, DFF, and 5-HMF for use as HPLC standards (and in oxidation experiments in the case of FFCA and DFF), and the precursors $\left(\mathrm{FeCl}_{3}, \mathrm{NaNO}_{3}\right.$, and $\left.\mathrm{NH}_{4} \mathrm{~F}\right)$ for the synthesis of hematite photoanode, were purchased from Sigma Aldrich( Stockholm, Sweden). For use in oxidation experiments, 5-HMF and HMFCA were synthesized and purified in our laboratory at high purity according to our previous study [30]. (2,2,6,6-Tetramethylpiperidin-1-yl)oxyl (TEMPO) and Trametes versicolor laccase (specific activity of $0.5 \mathrm{U} / \mathrm{mg}$ ) were purchased from Sigma Aldrich. Sodium sulfate and sodium hydroxide were purchased from Merck (Stockholm, Sweden). The photoelectrochemical (PEC) oxidation of the furan compounds was performed in a custommade PEC cell. The Ag/AgCl reference electrode was purchased from IJ Cambria Scientific Ltd (Llanelli, UK). The potentiostat from PalmSens (Houten, The Netherlands) and Ivium Stat (Eindhoven, The Netherlands) was used for the PEC studies.

\subsection{Hematite Photoanode Synthesis}

The hematite photoanode was prepared following the method reported by Vayssieres and coworkers [27]. Briefly, 0.15 $\mathrm{M}$ ferric chloride and $1 \mathrm{M}$ sodium nitrate solutions were adjusted to $\mathrm{pH} 1.1$ by dropwise addition of $1 \mathrm{M} \mathrm{HCl}$. The cleaned FTO substrates were immersed in this solution for $12 \mathrm{~h}$ and placed in an autoclave at a constant temperature of $100{ }^{\circ} \mathrm{C}$. The $\mathrm{FTO} / \alpha-\mathrm{Fe}_{2} \mathrm{O}_{3}$ electrodes were then rinsed with distilled water and ethanol, followed by annealing at $800{ }^{\circ} \mathrm{C}$ for $5 \mathrm{~min}$, and further modified by soaking in the fluoriderich iron-oxide electrolyte $\left(1 \mathrm{mM} \mathrm{NH}_{4} \mathrm{~F}\right.$ in $\left.0.15 \mathrm{M} \mathrm{FeCl}_{3}\right)$ for $5 \mathrm{~h}$ at $100{ }^{\circ} \mathrm{C}$ followed by rinsing with distilled water and subsequent annealing at $400{ }^{\circ} \mathrm{C}$ for $5 \mathrm{~min}$ to yield fluorinedoped $\mathrm{FTO} / \alpha-\mathrm{Fe}_{2} \mathrm{O}_{3} / \mathrm{FeOOH}$.

\subsection{Photoelectrochemical Oxidation of 5-HMF, HMFCA, FFCA, and DFF}

A solution of $10 \mathrm{mM}$ furan compounds, 5-HMF, DFF, HMFCA, and FFCA, respectively, was prepared in $50 \mathrm{~mL}$ of $1 \mathrm{M}$ sodium sulfate $\left(\mathrm{Na}_{2} \mathrm{SO}_{4}\right)$ with an average $\mathrm{pH}$ of 4.5 . The furan solutions were also prepared with other $\mathrm{pH}$ values, 9 and 12, by adjusting $\mathrm{pH}$ using $1 \mathrm{M} \mathrm{NaOH}$ solution. Then, $30 \mathrm{~mL}$ of each solution, with respective $\mathrm{pH}$ values, was used directly or mixed with 1 or $2 \mathrm{mg} / \mathrm{mL}$ (2,2,6,6-Tetramethylpiperidin-1-yl)oxyl (TEMPO) in the photoelectrochemical cell for photooxidation at room temperature. Control experiments at different $\mathrm{pH}$ values were performed in dark while maintaining the other conditions.

The photoelectrode for the PEC measurements was prepared by gently polishing all the edges with sandpaper, and connected to the crocodile clip, and the assembly was sealed with conductive silver paste and further covered with Teflon tape. The other three edges were coated with insulating epoxy. The current potential curve, also called linear sweep voltammetry (LSV), was recorded for all the photoelectrodes in the dark and in light under various conditions used in this study. The cold-white LED (MCWHL6-C1, Thor Labs, Mölndal, Sweden) was used as a light source for illuminating the hematite photoanode. The illumination intensity was maintained at $100 \mathrm{~mW} / \mathrm{cm}^{2}$ throughout the study. 
The LSVs were performed versus $\mathrm{Ag} / \mathrm{AgCl}$ reference electrode and converted to reversible hydrogen electrode voltage using Equation (1):

$$
\mathrm{V}_{\mathrm{RHE}}=\mathrm{V}_{\mathrm{Ag} / \mathrm{AgCl}}+0.1976+(0.059 \times \mathrm{pH})
$$

Moreover, photoelectrochemical oxidation of 5-HMF was performed using $1 \mathrm{mg} / \mathrm{mL}$ TEMPO at $\mathrm{pH} 12$ as well as using $2 \mathrm{mg} / \mathrm{mL}$ TEMPO. The photoelectrochemical oxidation of $5-\mathrm{HMF}$ at $\mathrm{pH} 9.0$ and 4.5 was performed with and without $2 \mathrm{mg} / \mathrm{mL}$ TEMPO. At $\mathrm{pH} 4.5$, we also tested the T. versicolor lacasse as the oxidation catalyst with and without TEMPO as the electron mediator. Five hundred microliter samples were collected at regular time intervals over the reaction time for HPLC analysis of the substrates, intermediates, and products.

\subsection{Product Analysis}

The concentrations of 5-HMF, FFA, FFCA, and FDCA were determined using HPLC (JASCO, Tokyo, Japan) equipped with a Bio-Rad Aminex HPX-87H column (connected to a guard column (Biorad, Richmond, CA, USA), refractive index detector (ERC, Kawaguchi, Japan), a JASCO UV detector operating at $254 \mathrm{~nm}$, and a JASCO intelligent autosampler. The column temperature was maintained at $65^{\circ} \mathrm{C}$ in a chromatographic oven (Shimadzu, Tokyo, Japan). Samples were diluted with Milli-Q quality water mixed with $20 \%(v / v) \mathrm{H}_{2} \mathrm{SO}_{4}(20 \mu \mathrm{L} / \mathrm{mL}$ sample), and then filtered using $0.45 \mu \mathrm{m}$ filter. A $40 \mu \mathrm{L}$ aliquot was injected in $0.5 \mathrm{mM} \mathrm{H}_{2} \mathrm{SO}_{4}$ mobile phase flowing at a rate of $0.4 \mathrm{~mL} / \mathrm{min}$. The peaks for the different compounds were confirmed and quantified using the corresponding external standards.

The photoconversion of 5-HMF was calculated using Equation (2):

$$
5-\mathrm{HMF} \text { conversion }(\%)=\frac{(\text { Initial concentration }- \text { Final concentration })}{(\text { Initial concentration })} \times 100
$$

The yield (\%) of the product formed was calculated using Equation (3):

$$
\text { Yield of product }(\%)=\frac{(\text { mol of product formed })}{(\text { mol of initial } 5-\mathrm{HMF})} \times 100
$$

The incident photon-to-current efficiency was calculated using Equation (4)

$$
I P C E=\frac{(|j|) \times 1239.8}{P \times \lambda} \times 100
$$

where $1239.8 \mathrm{~V}$ nm represents a multiplication of $h$ (Planck's constant) and $c$ (the speed of light), $P$ is the calibrated and monochromated illumination power density in $\mathrm{mW} / \mathrm{cm}^{2}$, and $\lambda$ is the illumination wavelength.

The Faradic efficiency based on the 5-HMF conversion into products was calculated using Equation (5).

$$
F E(\%)=\frac{\text { mol of HMF Converted }}{\text { total charge passed }} \times n \times F \times 100
$$

where $n$ is the number of electrons transferred during 5-HMF oxidation $\left(6 \mathrm{e}^{-}\right)$and $F$ is the Faraday constant $96,485.3 \mathrm{~s} \mathrm{~A} \mathrm{~mol}^{-1}$.

\section{Conclusions}

In conclusion, this study demonstrates 99.2\% 5-HMF conversion to FDCA with a yield of $>90 \%$ using hematite photoelectrode under visible illumination at $\mathrm{pH}>12$, ambient temperature $\left(21 \pm 1{ }^{\circ} \mathrm{C}\right)$, and atmospheric pressure in the presence of TEMPO. The 5HMF oxidation follows different routes at $\mathrm{pH}$ above and below 12, i.e., via HMFCA and DFF, respectively. The rate-limiting steps in the respective cases are the oxidation of HMFCA and FFCA. Besides FDCA, even the intermediate oxidation products HMFCA, DFF, and FFCA bearing different functionalities (hydroxyl, aldehyde, and carboxyl), formed 
during the PEC oxidation, constitute highly interesting building blocks for novel polymer structures. This study serves as the foundation for the photo-conversion of 5-HMF that can be enhanced in the future for selective production of FDCA by synthesizing high surface area Earth-abundant hematite photoelectrodes and subsequent modification with a suitable dopant. As is well known, the large-scale application of TEMPO is limited by its high cost and potential toxicity. It would thus be important to consider alternative strategies including polymer-supported TEMPO to enable its recycling and/or using other electron mediators that are less expensive like TEMPOL (4-hydroxy-TEMPO) or those based on natural resources like sinapic acid and syringaldehyde [34,37-41].

Supplementary Materials: The following are available online at https:/ / www.mdpi.com/article/10.3 390/catal11080969/s1, Figure S1 (a) X-ray diffraction patterns for the bare (black trace) and modified hematite (red trace); (b) and (c) show the planar top view scanning electron micrograph for bare and modified hematite photoanode, respectively, before the PEC experiment; while (d) shows a planar top view scanning electron micrograph after the $20 \mathrm{~h}$ PEC run. The bar represents $1 \mu \mathrm{m}$. The bar represents $1 \mu \mathrm{m}$. Figure S2 LSVs for the bare and modified hematite photoanodes at different $\mathrm{pH}$ values $(4.5,9.0$, and 12.5) in $1 \mathrm{M} \mathrm{Na}_{2} \mathrm{SO}_{4}$ solution, and the corresponding dark current for (c) bare and (d) modified photoanodes, respectively. The dark current response for 5-HMF oxidation at (e) pH 12.5, (f) 9.0, and (g) 4.5 are also shown. Table S1 $V_{\text {onset }}$ potentials obtained for modified hematite under different $\mathrm{pH}$ conditions and the net photocurrent density recorded at $1.4 V_{R H E}$ (in square bracket, orange color). Figure S3 Cyclic voltammograms recorded in $\mathrm{Na}_{2} \mathrm{SO}_{4}+$ TEMPO with and without 5-HMF in dark and under illumination at $\mathrm{pH}$ (a) 12.5, (b) $\mathrm{pH}$ 9.0, and (c) $\mathrm{pH}$ 4.5. Figure S4 Chronoamperometry response for 5-HMF oxidation recorded under visible illumination and $1.1 V_{R H E}$ at $100 \mathrm{~mW} / \mathrm{cm}^{2}$ for $\alpha-\mathrm{Fe}_{2} \mathrm{O}_{3}-\mathrm{FeOOH}$ in $1 \mathrm{M} \mathrm{Na}_{2} \mathrm{SO}_{4}$ solution at $\mathrm{pH}$ 4.5. Figure S5 Chronoamperometry response for (a) 5-HMF, (b) FFCA, (c) HMFCA, and (d) DFF oxidation recorded under visible illumination and $1.1 V_{R H E}$ at $100 \mathrm{~mW} / \mathrm{cm}^{2}$ for $\alpha-\mathrm{Fe}_{2} \mathrm{O}_{3}-\mathrm{FeOOH}$ in $1 \mathrm{M} \mathrm{Na}_{2} \mathrm{SO}_{4}$ solution (pH 9.0). Figure S6 LSVs for the modified hematite photoanode recorded for different furan compounds as substrates at $\mathrm{pH} 9.0$ in $1 \mathrm{M} \mathrm{Na}_{2} \mathrm{SO}_{4}$ solution. Figure S7 HPLC chromatograms of the photooxidation of (a) DFF, (b) HMFCA, and (c) FFCA in $1 \mathrm{M} \mathrm{Na}_{2} \mathrm{SO}_{4}$ solution at $\mathrm{pH} 12.5$ with $2 \mathrm{mg} / \mathrm{mL}$ TEMPO. Table S2 Comparison of the system presented in this study with other photoelectrochemical or photocatalytic systems reported in the literature on 5-HMF oxidation to FDCA.

Author Contributions: A.K., M.S., and R.H.-K. conceptualized the project. A.K., M.S., T.P., and R.H.-K. designed the experiments. A.K. prepared the photoelectrodes and performed the PEC. measurements. M.S. prepared the furan compounds for the study and performed the HPLC analyses. Q.S. performed the XRD on the photoanode samples. J.U. helped with the chronoamperometry and PEC instrumentation setup and revising the manuscript. A.K. and R.H.-K. wrote the manuscript with important inputs from the co-authors. T.P. and R.H.-K. provided the resources, supervision, arranged funding, and project administration. All authors have read and agreed to the published version of the manuscript.

Funding: T.P. acknowledges financial support from Swedish Energy Agency (grant no. 50709-1 and 44651-1) and Swedish Research Council (grant no. 2018-05090). R.H.-K. acknowledges financial support from the Swedish Foundation for Strategic Environmental Research (Mistra, grant no. 2016/1489), Swedish Research Agency Formas (grant no. 942-2016-33), and Lantmännen Research Foundation (grant no. 2019H045).

Data Availability Statement: The data shown in this paper are available upon request.

Acknowledgments: A.K. acknowledges assistance from NanoLund cleanroom facilities for the synthesis of photoelectrodes.

Conflicts of Interest: The authors declare no competing financial interest. 


\section{References}

1. Chemicals. Available online: https://www.iea.org/fuels-and-technologies/chemicals (accessed on 1 June 2021).

2. Davidson, M.G.; Elgie, S.; Parsons, S.; Young, T.J. Production of HMF, FDCA and their derived products: A review of life cycle assessment (LCA) and techno-economic analysis (TEA) studies. Green Chem. 2021, 23, 3154-3171. [CrossRef]

3. Gratzel, M. Photoelectrochemical cells. Nature 2001, 414, 338-345. [CrossRef]

4. Vennestrøm, P.; Osmundsen, C.M.; Christensen, C.; Taarning, E. Beyond petrochemicals: The renewable chemicals industry. Angew. Chem. Int. Ed. 2011, 50, 10502-10509. [CrossRef]

5. Cha, H.G.; Choi, K.-S. Combined biomass valorization and hydrogen production in a photoelectrochemical cell. Nat. Chem. 2015, 7, 328. [CrossRef] [PubMed]

6. Lianos, P. Production of electricity and hydrogen by photocatalytic degradation of organic wastes in a photoelectrochemical cell: The concept of the photofuelcell: A review of a re-emerging research field. J. Hazard. Mater. 2011, 185, 575-590. [CrossRef] [PubMed]

7. Roger, I.; Shipman, M.A.; Symes, M.D. Earth-abundant catalysts for electrochemical and photoelectrochemical water splitting. Nat. Rev. Chem. 2017, 1, 3. [CrossRef]

8. Lhermitte, C.R.; Sivula, K. Alternative oxidation reactions for solar-driven fuel production. ACS Catal. 2019, 9, 2007-2017. [CrossRef]

9. Kawde, A.; Annamalai, A.; Amidani, L.; Boniolo, M.; Kwong, W.L.; Sellstedt, A.; Glatzel, P.; Wågberg, T.; Messinger, J. Photoelectrochemical hydrogen production from neutral phosphate buffer and seawater using micro-structured p-Si photo-electrodes functionalized by solution-based methods. Sustain. Energy Fuels 2018, 2, 2215-2223. [CrossRef]

10. Kawde, A.; Annamalai, A.; Sellstedt, A.; Uhlig, J.; Wågberg, T.; Glatzel, P.; Messinger, J. More than protection: The function of $\mathrm{TiO}_{2}$ interlayers in hematite functionalized Si photoanodes. Phys. Chem. Chem. Phys. 2020, 22, 28459-28467. [CrossRef] [PubMed]

11. Kawde, A.; Annamalai, A.; Sellstedt, A.; Glatzel, P.; Wågberg, T.; Messinger, J. A microstructured p-Si photocathode outcompetes $\mathrm{Pt}$ as a counter electrode to hematite in photoelectrochemical water splitting. Dalton Trans. 2019, 48, 1166-1170. [CrossRef]

12. Luo, J.; Steier, L.; Son, M.-K.; Schreier, M.; Mayer, M.T.; Graätzel, M. $\mathrm{Cu}_{2} \mathrm{O}$ nanowire photocathodes for efficient and durable solar water splitting. Nano Lett. 2016, 16, 1848-1857. [CrossRef]

13. Liang, Y.; Messinger, J. Improving $\mathrm{BiVO}_{4}$ photoanodes for solar water splitting through surface passivation. Phys. Chem. Chem. Phys. 2014, 16, 12014-12020. [CrossRef]

14. Werpy, T.; Petersen, G. Top Value Added Chemicals from Biomass: Volume I-Results of Screening for Potential Candidates from Sugars and Synthesis Gas; National Renewable Energy Lab.: Golden, CO, USA, 2004.

15. Román-Leshkov, Y.; Chheda, J.N.; Dumesic, J.A. Phase modifiers promote efficient production of hydroxymethylfurfural from fructose. Science 2006, 312, 1933-1937. [CrossRef]

16. Jacquel, N.; Saint-Loup, R.; Pascault, J.-P.; Rousseau, A.; Fenouillot, F. Bio-based alternatives in the synthesis of aliphatic-aromatic polyesters dedicated to biodegradable film applications. Polymer 2015, 59, 234-242. [CrossRef]

17. Davis, S.E.; Houk, L.R.; Tamargo, E.C.; Datye, A.K.; Davis, R.J. Oxidation of 5-hydroxymethylfurfural over supported Pt, Pd and Au catalysts. Catal. Today 2011, 160, 55-60. [CrossRef]

18. Liguori, F.; Barbaro, P.; Calisi, N. Continuous-Flow Oxidation of HMF to FDCA by Resin-Supported Platinum Catalysts in Neat Water. ChemSusChem 2019, 12, 2558-2563. [CrossRef]

19. Xu, S.; Zhou, P.; Zhang, Z.; Yang, C.; Zhang, B.; Deng, K.; Bottle, S.; Zhu, H. Selective oxidation of 5-hydroxymethylfurfural to 2, 5-furandicarboxylic acid using $\mathrm{O}_{2}$ and a photocatalyst of Co-thioporphyrazine bonded to g-C3N4. J. Am. Chem. Soc. 2017, 139, 14775-14782. [CrossRef]

20. Barwe, S.; Weidner, J.; Cychy, S.; Morales, D.M.; Dieckhöfer, S.; Hiltrop, D.; Masa, J.; Muhler, M.; Schuhmann, W. Electrocatalytic Oxidation of 5-(Hydroxymethyl) furfural Using High-Surface-Area Nickel Boride. Angew. Chem. Int. Ed. 2018, 57, 11460-11464. [CrossRef]

21. Mi, Q.; Zhanaidarova, A.; Brunschwig, B.S.; Gray, H.B.; Lewis, N.S. A quantitative assessment of the competition between water and anion oxidation at WO 3 photoanodes in acidic aqueous electrolytes. Energy Environ. Sci. 2012, 5, 5694-5700. [CrossRef]

22. Fuku, K.; Wang, N.; Miseki, Y.; Funaki, T.; Sayama, K. Photoelectrochemical Reaction for the Efficient Production of Hydrogen and High-Value-Added Oxidation Reagents. ChemSusChem 2015, 8, 1593-1600. [CrossRef]

23. Han, G.; Jin, Y.-H.; Burgess, R.A.; Dickenson, N.E.; Cao, X.-M.; Sun, Y. Visible-light-driven valorization of biomass intermediates integrated with $\mathrm{H} 2$ production catalyzed by ultrathin Ni/CdS nanosheets. J. Am. Chem. Soc. 2017, 139, 15584-15587. [CrossRef] [PubMed]

24. Chen, Z.; Dinh, H.N.; Miller, E. Photoelectrochemical Water Splitting; Springer: New York, NY, USA, 2013; Volume 344, ISBN 978-1-4614-8297-0.

25. Vuyyuru, K.R.; Strasser, P. Oxidation of biomass derived 5-hydroxymethylfurfural using heterogeneous and electrochemical catalysis. Catal. Today 2012, 195, 144-154. [CrossRef]

26. Kim, J.Y.; Jang, J.W.; Youn, D.H.; Magesh, G.; Lee, J.S. A stable and efficient hematite photoanode in a neutral electrolyte for solar water splitting: Towards stability engineering. Adv. Energy Mater. 2014, 4, 1400476. [CrossRef]

27. Vayssieres, L.; Beermann, N.; Lindquist, S.-E.; Hagfeldt, A. Controlled aqueous chemical growth of oriented three-dimensional crystalline nanorod arrays: Application to iron (III) oxides. Chem. Mater. 2001, 13, 233-235. [CrossRef]

28. Kormányos, A.; Kecsenovity, E.; Honarfar, A.; Pullerits, T.; Janáky, C. Hybrid FeNiOOH $/ \alpha-\mathrm{Fe}_{2} \mathrm{O}_{3} /$ Graphene Photoelectrodes with Advanced Water Oxidation Performance. Adv. Funct. Mater. 2020, 30, 2002124. [CrossRef] 
29. Wang, T.; Long, X.; Wei, S.; Wang, P.; Wang, C.; Jin, J.; Hu, G. Boosting Hole Transfer in the Fluorine-Doped Hematite Photoanode by Depositing Ultrathin Amorphous FeOOH/CoOOH Cocatalysts. ACS Appl. Mater. Interfaces 2020, 12, 49705-49712. [CrossRef]

30. Sayed, M.; Warlin, N.; Hulteberg, C.; Munslow, I.; Lundmark, S.; Pajalic, O.; Tunå, P.; Zhang, B.; Pyo, S.-H.; Hatti-Kaul, R. 5-Hydroxymethylfurfural from fructose: An efficient continuous process in a water-dimethyl carbonate biphasic system with high yield product recovery. Green Chem. 2020, 22, 5402-5413. [CrossRef]

31. Bragd, P.; Van Bekkum, H.; Besemer, A. TEMPO-mediated oxidation of polysaccharides: Survey of methods and applications. Top. Catal. 2004, 27, 49-66. [CrossRef]

32. Sivula, K.; Le Formal, F.; Grätzel, M. Solar water splitting: Progress using hematite $\left(\alpha-\mathrm{Fe}_{2} \mathrm{O}_{3}\right)$ photoelectrodes. ChemSusChem 2011, 4, 432-449. [CrossRef]

33. Annamalai, A.; Shinde, P.S.; Subramanian, A.; Kim, J.Y.; Kim, J.H.; Choi, S.H.; Lee, J.S.; Jang, J.S. Bifunctional TiO 2 underlayer for $\alpha-\mathrm{Fe}_{2} \mathrm{O}_{3}$ nanorod based photoelectrochemical cells: Enhanced interface and $\mathrm{Ti}^{4+}$ doping. J. Mater. Chem. A 2015, 3, 5007-5013. [CrossRef]

34. Gerken, J.B.; Pang, Y.Q.; Lauber, M.B.; Stahl, S.S. Structural Effects on the pH-Dependent Redox Properties of Organic Nitroxyls: Pourbaix Diagrams for TEMPO, ABNO, and Three TEMPO Analogs. J. Org. Chem. 2017, 83, 7323-7330. [CrossRef] [PubMed]

35. Riva, S. Laccases: Blue enzymes for green chemistry. TRENDS Biotechnol. 2006, 24, 219-226. [CrossRef]

36. Honarfar, A.; Mourad, H.; Lin, W.; Polukeev, A.; Rahaman, A.; Abdellah, M.; Chábera, P.; Pankratova, G.; Gorton, L.; Zheng, K. Photoexcitation Dynamics in Electrochemically Charged CdSe Quantum Dots: From Hot Carrier Cooling to Auger Recombination of Negative Trions. ACS Appl. Energy Mater. 2020, 3, 12525-12531. [CrossRef]

37. Ciriminna, R.; Pagliaro, M. Industrial oxidations with organocatalyst TEMPO and its derivatives. Org. Process Res. Dev. 2010, 14, 245-251. [CrossRef]

38. Dijksman, A.; Arends, I.W.; Sheldon, R.A. Polymer immobilised TEMPO (PIPO): An efficient catalyst for the chlorinated hydrocarbon solvent-free and bromide-free oxidation of alcohols with hypochlorite. Chem. Commun. 2000, 66, 271-272. [CrossRef]

39. Liu, S.; Liang, H.; Sun, T.; Yang, D.; Cao, M. A recoverable dendritic polyamidoamine immobilized TEMPO for efficient catalytic oxidation of cellulose. Carbohydr. Polym. 2018, 202, 563-570. [CrossRef]

40. Mani, P.; Fidal Kumar, V.T.; Keshavarz, T.; Chandra, T.S.; Kyazze, G. The role of natural laccase redox mediators in simultaneous dye decolorization and power production in microbial fuel cells. Energies 2018, 11, 3455. [CrossRef]

41. Zhang, K.; Wu, Y.; Huang, J.; Liu, Y. Environmentally Friendly and Recyclable Natural-Mediator-Modified Magnetic Nanoparticles for Laccase-Catalyzed Decolorization. J. Chem. 2019, 2019, 4140565. [CrossRef] 